\title{
Cytotoxic and Cell Cycle Arrest of Total Alkaloids Extracted from Chelidonium Majus Against Human Colon Cancer (HCT-116).
}

\author{
Yasir B. Fadhil *, Khuldood W. Al-Sammarraie and Nedhal Abdul Mohaimen \\ Department of Biotechnology, College of Science, Al-Nahrain University, Baghdad-Iraq. \\ *Corresponding Author: yasiralali88@gmail.com
}

\begin{abstract}
Chelidonium majus, commonly known as Greater Celandine is a plant widely distributed in nature the plant been used in various traditional system of medicine to treat various disorders. Antitumor activity of total extracted alkaloid of this plant have been studied, there are few studies that examine the properties of the total extracted alkaloids. Thus the objective of this project is to investigate cytotoxic effects of total alkaloid extracted from $C$. majus against Human colon cancer cell line. Powdered plant material was extracted with methanol by using Soxhlet installation. The extract subjected for acid-base extraction and purification with chloroform to obtain total alkaloids. Cytotoxicity effect of total alkaloids was estimated using MTT-assay in addition to the determination of apoptosis/necrosis FITC Annexin V /PI assay and Cell Cycle Analysis by Pi Staining. It was found that Chelidonium majus contain high amount of total alkaloids where the yield of total extracted alkaloids was about $(2.146 \%)$ of total dried weight. The total extracted alkaloids from $C$. majus showed high significant cytotoxicity effect on (HCT-116) cell lines which was in a dose dependent way, where the $\mathrm{IC}_{50}$ was $(67.43 \mu \mathrm{g} / \mathrm{ml})$. Annexin V-FITC assay showed that total alkaloids from $C$. majus is strong inducer of apoptosis in HCT-116 cell line. While, the cell cycle arrest evaluation showed that the extract arrests cell cycle progression by significantly restricting cells in different phases $(\mathrm{G} 1, \mathrm{~S}, \mathrm{G} 2 / \mathrm{M})$ in a dose dependent way. It is concluded that the plant contains a large quantity of total alkaloids. The total extracted alkaloids showed cytotoxic activity against colorectal cancer (HCT-116) cell line which was in dose dependent manner indicating that the extract could be used in cancer therapy.
\end{abstract}

[DOI: $10.22401 /$ JNUS.21.3.16]

Keywords: Chelidonium majus, Cell culture, MTT assay, FACS/PI analysis, cell cycle arrest.

\section{Introduction}

Herbalism (also herbology or herbal medicine) means use of plants for medicinal purposes. Archaeological studies indicate the use of medicinal plants dates back to the Paleolithic age, approximately 60,000 years ago. Written evidence of herbal remedies dates back over 5,000 years, to the Sumerians, who compiled lists of plants [1]. Normal cells are constantly subjected to signals which dictate their division and death. Cancer cells develop a degree of autonomy from these signals, resulting in uncontrolled growth and proliferations. There are various types of cancer which effect lung, prostate tissue, colon, etc. and the colorectal cancer accounts for over $9 \%$ of all cancer fatal incidences. Colorectal cancer is the third most common cancer and the third leading cause of mortality among men and women. In 2015, it was estimated about 132,700 new cases and about
49,700 deaths from colorectal cancer [2,3]. Approximately $30 \%$ to $50 \%$ of patients with this disease will develop liver metastases at the time of presentation or later during the course of their disease. [4,5]. The most commonly used cancer chemotherapy drugs include mainly alkylating agents, antimetabolites, antitumor antibiotics, platinum analogues and natural anticancer agents [3]. Due to the increasing rate of mortality associated with cancer and adverse or toxic side effects of cancer chemotherapy and radiation therapy, discovery of new anticancer agents derived from nature has begun especially plants and the screening of medicinal plants [4]. Chelidonium majus, commonly known as Greater Celandine is a plant widely distributed throughout nature. It bears yellow flowers and is nearly always to be found growing in disturbed soils along old walls and housing foundations [5]. Chelidonium majus $L$. is a 
medicinal herb used in various traditional systems of medicine to treat ulcer, cancer, oral infection, liver disorders, chronic bronchitis, asthma, etc [6]. EMA/HMPC, (2011) has described the medicinal uses of this plant in a national and European Pharmacopoeia in wellestablished documents. Different parts of this plant contain yellow-orange latex rich with alkaloids. Numerous therapeutically important alkaloidal constituents such as chelidonine, chelerythrine, sanguinarine, berberine and so on $[6,5]$. Due to the presence of the isoquinoline alkaloids and flavonoids components in $C$. majus may play an important role in both cancer chemoprevention through its antioxidant activity and modern cancer chemotherapy as cytotoxic and apoptosis-inducing agent [6]. Numerous studies show a high content of bioactive compounds with anti-parasitic [9], antiinflammatory [10], antifungal [11], antimicrobial and cytotoxic effects [8-12]. The plant has been widely used in traditional and modern medicine for the treatment of liver diseases, gastrointestinal tract, and there are also some data on the use of this herb for the prevention and treatment of cancer and tumors [6-7].

In the present study, total alkaloids extracted from Chelidonium majus was evaluated for its anti-cancer properties on HCT-116 cell line (human colon cancer) using MTT-assay, as well as investigations the effect of the extract activity, cell cycle arrest and apoptosis on selected cancer cell line.

\section{Materials and methods}

Preparation of plant material and extraction Plant extraction and purification were done according to the procedure described by (Bugatti et al., 1991) and (Harborne JB., (1984)) [14,20] in brief:

Chelidonium majus was bought from a Botanic Planet (Brampton, Ontario, Canada) as dried aerial parts. A quantity of 100 grams of the plant material was reduced to powder by using grinder and packed loosely in thimble. Plant extracted against $500 \mathrm{ml}$ of methanol (85\%) using Soxhlet installation for $24 \mathrm{hrs}$. The extract then half evaporated and then combined in beaker. $\mathrm{pH}$ was to 2 by using sulphoric acid (Checked by $\mathrm{PH}$ meter), then extracted in a separatory funnel with $100 \mathrm{ml}$ chloroform. Two layers (A for aqueous layer, $\mathrm{A}^{+}$for non-polar layer) were collected separately. The aqueous layer (A) basified by ammonium hydroxide until the $\mathrm{pH}$ reached to the value of 9 and extracted again with chloroform in separatory funnel. Two layers were also collected separately (B for aqueous layer, $\mathrm{B}^{+}$for non-polar layer). B layer was extracted again with chloroform till Dragendorff's test gave negative test. $\mathrm{A}, \mathrm{A}^{+}$ and $\mathrm{B}^{+}$phases were concentrated by evaporation then dried and calculated for total alkaloid. Note: during extraction and purification steps $\left(\mathrm{A}, \mathrm{A}^{+}, \mathrm{B}\right.$ and $\mathrm{B}^{+}$layers) samples were collected and detected for total alkaloids using Dragendorff's and Mayer's test.

\section{Cell culture}

Human colon cancer (HCT-116) cell line was obtained from National Center for Cell Science (NCCS Pune / India). The cells were maintained in RPMI-1640 medium supplemented with $10 \%$ fetal bovine serum, 10ug/ml Ciprofloxacin (all from HiMedia, India). Cells were incubated at $37^{\circ} \mathrm{C}$ in an atmosphere of $5 \% \mathrm{CO}_{2}$ and absolute humidity Cell number and viability were determined using trypan blue according to Freshney (2012) procedure [15].

\section{Cytotoxicity study \\ MTT assay}

Cell viability and cytotoxicity in response to total alkaloids extract was applied including the mitochondrial metabolic activity by (3(4,5-dimethylthiazol-2-yl)-2,5-

diphenyltetrazolium bromide) tetrazolium (MTT) assay according to Mosmann., (1983) [16] and Freshney., (2012) procedures. Cell suspensions were seeded in a 96-well plate at required cell density $\left(2 * 10^{4}\right.$ cells per well), without the test agent and then incubated to grow and adhere for about 12 hours. After incubation the plat were took out and examined under inverted microscope to ensure cells adherent. Appropriate concentrations of the extracted total alkaloid were added $(5,50,100,150$ to $200 \mu \mathrm{g} / \mathrm{ml})$ and then incubated for $24 \mathrm{hrs}$ at $37^{\circ} \mathrm{C}$ in $5 \% \quad \mathrm{CO}_{2}$ atmosphere. After incubation period, $10 \%$ of 
MTT reagent $(5 \mathrm{mg} / \mathrm{ml})$ was added and and incubated for 3 hours. During the time, metabolically active viable cells reduced soluble yellow MTT to insoluble purple formazan, due to activity of mitochondrial dehydrogenase. The MTT reagent was carefully removed and then $100 \mu \mathrm{l}$ of dimethylsulfoxide (DMSO) was added to each well. The absorbance values read by ELISA reader at $570 \mathrm{~nm}$. The percentage of inhibition was calculated according to the following equation.

Inhibition $\%=100-[$ (optical density of test wells/optical density of control wells)] $\times$ 100. Experiment controls were medium control without cells, medium with cells but without total alkaloids (negative control) and medium with cells treated with berberine (positive control).

\section{Flow-cytometric analysis}

HCT-116 cell line cultured in a 6-well plate at density $\left(3 \times 10^{5}\right.$ cells $\left./ \mathrm{ml}\right)$ and incubated in a $\mathrm{CO}_{2}$ incubator at $37^{\circ} \mathrm{C}$ for 24 hrs. Cells were washed with PBS and treated with the required concentration of experimental compounds $\left(\mathrm{IC}_{25}-33.7 \mu \mathrm{g}, \mathrm{IC}_{50^{-}}\right.$ $67.4 \mu \mathrm{g}$ and $\mathrm{IC}_{75}-101 \mu \mathrm{g}$ of total extracted alkaloid). A positive control $(2,4,6 \mu \mathrm{M})$ of berberine were used.

\section{Annexin V-FITC/PI assay}

HCT -116 cells were washed with PBS then removed and trypsin-EDTA solution was added and incubated at $37^{\circ} \mathrm{C}$ for $3-4 \mathrm{~min}$. the culture medium poured back into their respective wells and the cells harvested directly into $12 \times 75 \mathrm{~mm}$ polystyrene tubes and centrifuged. Cells were suspended in $1 \mathrm{X}$ binding buffer at a concentration of $1 \times 10^{6}$ cells $/ \mathrm{ml} .100 \mu \mathrm{l}$ of the solution transferred to a $5 \mathrm{ml}$ culture tube. Aliquot of $5 \mu \mathrm{l}$ of FITC Annexin $\mathrm{V}$ was added then incubated for 15 min at room temperature $\left(25^{\circ} \mathrm{C}\right)$ in the dark. After incubation $5 \mu \mathrm{l}$ of PI and $400 \mu \mathrm{l}$ of $1 \mathrm{X}$ Binding Buffer Added to each tube and vortexed gently. The data were immediately recorded by flow- cytometry after addition of PI. BD Biosciences FITC Annexin V Apoptosis Detection Kit I (Technical Data Sheet, Catalog no. 556547) [17].

\section{Cell cycle analysis by $P i$ staining}

HCT-116 cells were cultured in a 6-well plate at density of $3 \times 10^{5}$ cells $/ \mathrm{ml}$ and incubated in a $\mathrm{CO}_{2}$ incubator overnight at $37^{\circ} \mathrm{C}$ for $24 \mathrm{hrs}$. Cells were washed with PBS and treated with the required concentration of experimental compounds $\left(\mathrm{IC}_{25}-33.7 \mu \mathrm{g}, \mathrm{IC}_{50^{-}}\right.$ $67.4 \mu \mathrm{g}$ and $\mathrm{IC}_{75}-101 \mu \mathrm{g}$ of total alkaloids). Positive control $(2,4,6 \mu \mathrm{M})$ of berberine was used and incubated for $24 \mathrm{hrs}$. After incubation cells were harvested and washed in PBS and fixed by adding $1 \mathrm{ml}$ cold $70 \%$ ethanol then kept in ice for 30 minutes. Centrifugation for $5 \mathrm{~min}$. at high speed run and the supernatant being carefully descended and washed twice with PBS. 50 $\mu$ l of RNase A solution were added directly to pellet. To ensure that only DNA is stained (PI stains all nucleic acids). $400 \mu \mathrm{l}$ of PI solution per million cells were added directly to cells in RNase A solution and mixed well. Cells were incubated for $10 \mathrm{~min}$. at room temperature and analyzed by flow cytometry [18].

Experimental design and statistical analysis.

The experimental were designed according to the completely randomized design (CRD). The Statistical Analysis System- SAS (2014) program was used to determine differences in concentration (viability \%). Least significant differences -LSD test (ANOVA) was used to compare between the significance between the means [19].

\section{Results}

Estimation of total alkaloids. The results showed that total alkaloids in C. majus extract was as follows:

$$
\begin{aligned}
\% \text { Total alkaloids } & =\frac{\text { wt. of the residue }}{\text { wt. of } C \cdot \text { majus }} \times 100 \\
\text { yield } \% & =\frac{2.146 \mathrm{~g}}{100 \mathrm{~g}} \times 100
\end{aligned}
$$

yield of total alkaloids in $C$. majus extract $=2.146 \%$

The dried powdered leaves $(100 \mathrm{~g})$ yield a quantity of $(2.146 \mathrm{~g})$ residue of the total alkaloids as shown in table. The results indicated that yield \% of total alkaloids in $100 \mathrm{~g}$ C. majus was $2.146 \%$ of the dried leaves.

Qualification of total alkaloids by Dragendorff's test. 
About two millilitres of Dragendorff's reagent were added to the obtained samples of extracted alkaloids, an orange-brown precipitate was observed after the addition of Dragendorrf's which indicated presence of alkaloids.

Detection of total alkaloids by Mayer reagent.

Mayer's reagent was added to a portion of the extracted alkaloid in a Petri plate. An opalescence or creamy white precipitate was seen, indicating presence of alkaloids. In both reagents the aqueous layer (A for acid fraction) was showing a positive precipitate indicating presence of salt alkaloids which were soluble in aqueous portion. The chloroform layer $\left(\mathrm{A}^{+}\right.$for acid fraction) was also showing a positive precipitate which indicated presence of neutral and weak basic alkaloids. The second aqueous layer ( $\mathrm{B}$ for basic fraction) was negative test to both of reagents indicating the absence of alkaloids while the chloroform portion $\left(\mathrm{B}^{+}\right.$for basic fraction) was positive test to both of reagents this indicate that basic alkaloid was in organic layer.

Cytotoxicity effect of total alkaloids extracted from $C$. majus.

In this experiment, the methanolic extract of $C$. majus showed cytotoxicity effect on viability of HCT-116 (human colon cancer) cell line Fig.(1). The results demonstrated that treatment of cells with $C$. majus Alkaloid extract decreased the viability of cells in a dose-dependent manner Fig.(2). The

Table (1)

Cytotoxic effect of total extracted alkaloids from C. majus on HCT-116 after 24hrs exposure time along with positive control berberine.

\begin{tabular}{|c|c|c|c|}
\hline $\begin{array}{c}\text { Total alkaloids } \\
\text { Concentration }(\mu \mathrm{g} / \mathrm{ml})\end{array}$ & $\begin{array}{l}\text { Mean } \pm \text { SE of } \\
\text { Viability }(\%)\end{array}$ & $\begin{array}{c}\text { Berberine } \\
\text { Concentration } \\
(\mu \mathrm{M} / \mathrm{ml})\end{array}$ & $\begin{array}{c}\text { Mean } \pm \text { SE of } \\
\text { Viability }(\%) \text { HCT- } \\
116\end{array}$ \\
\hline Control & \multicolumn{3}{|c|}{$100.00 \pm 0.00 \mathrm{a}$} \\
\hline 5 & $81.51 \pm 4.50 \mathrm{~b}$ & 5 & $90.07 \pm 3.45 \mathrm{~b}$ \\
\hline 50 & $58.09 \pm 1.45 \mathrm{c}$ & 25 & $58.84 \pm 1.08 \mathrm{~b}$ \\
\hline 100 & $48.13 \pm 0.97 \mathrm{~d}$ & 50 & $48.79 \pm 0.40 \mathrm{c}$ \\
\hline 150 & $37.10 \pm 0.89 \mathrm{e}$ & 75 & $38.62 \pm 0.52 \mathrm{~d}$ \\
\hline 200 & $33.16 \pm 1.71 \mathrm{e}$ & 100 & $32.68 \pm 1.01 \mathrm{e}$ \\
\hline$P$-value & 0.0001 & $P$-value & $* * 0.0001$ \\
\hline
\end{tabular}


Total alkaloids of $C$. majus induce apoptosis in HCT-116 cell line

Flow cytometric analysis of assay Annexin V-FITC/PI apoptosis assay showed that treatment of HCT-116 cell line with the (IC25, IC 50, IC75) concentrations of extract induced cell death in high percent and negligible percent of treated cells were necrotic as shown in Fig.(3).

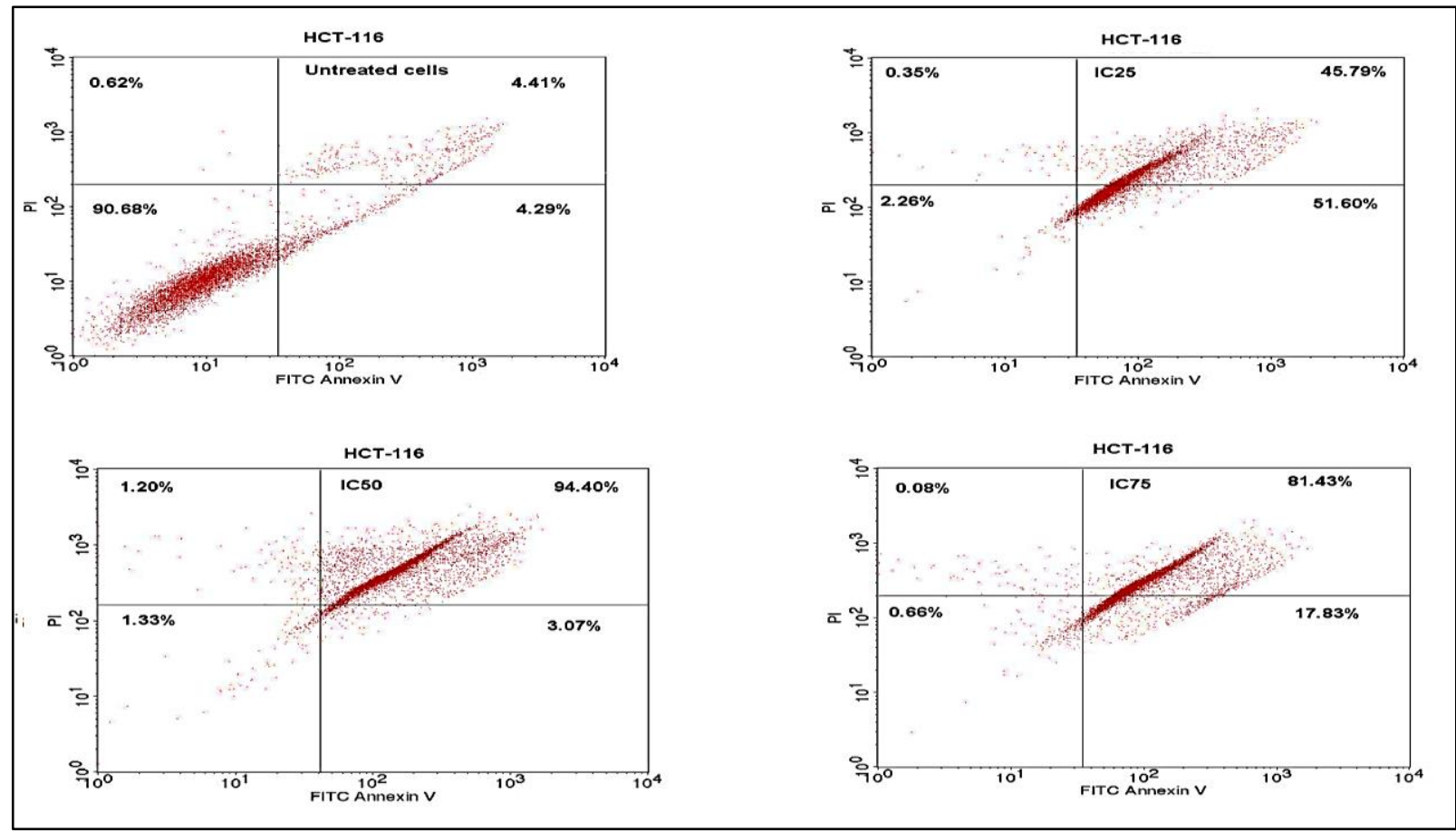

Fig.(3): Flow cytometric analysis of Annexin V-FITC/PI staining. Dot plots present percentage of viable, early apoptotic, late apoptotic and necrotic cells in untreated (control)and treated (total alkaloids) HCT116 cells. Lower left quadrant (A) represents viable cells (Annexin V/PI), lower right (B) early apoptotic (Annexin V+PI-), upper right $(C)$ late apoptotic (Annexin $V+P I+)$ and upper left (D) necrotic cells (Annexin V-PI +).

Results obtained by Annexin V-FITC/PI apoptosis assay showed that total extracted alkaloid from $C$. majus is strong inducer of apoptosis in HCT-116 cell line.

C. majus extract induce cell cycle arrest Incubation of HCT-116 for 24hrs with the extract using three different concentrations (IC25, IC50, IC75) resulted in accumulation of cells in different phases, with concomitant reduction of cell percentage in G0/G1 phase as shown in Fig.(4). The percentage of cells accumulated in $\mathrm{G} 2 / \mathrm{M}$ phase in Untreated cells (control) was $29.85 \%$, with $\mathrm{IC}_{25}$ was $28.25 \%$, while with $\mathrm{IC}_{50}$ was $19.91 \%$ and $50.26 \%$ with $\mathrm{IC}_{75}$. 


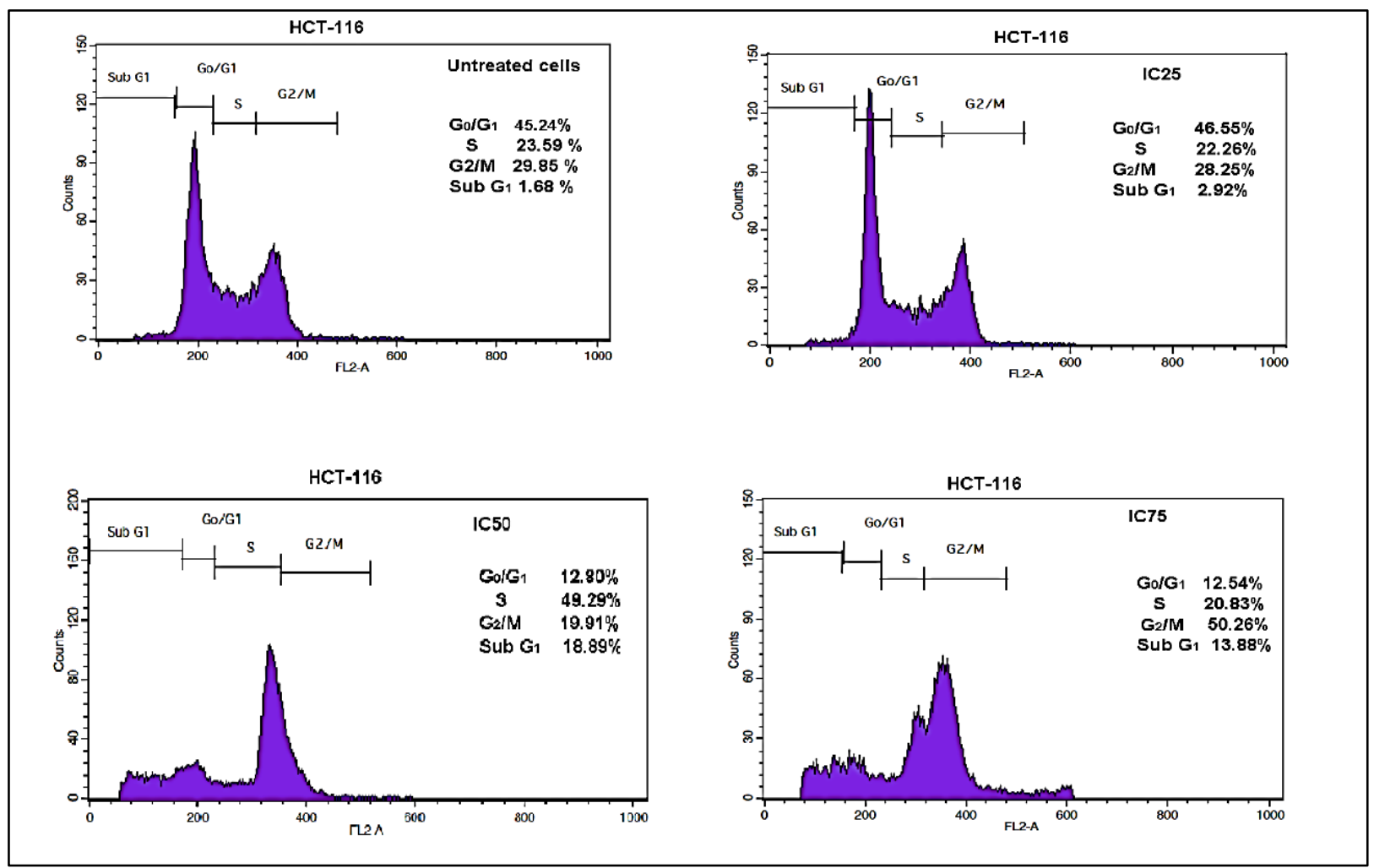

Fig.(4): Effect of C. majus extract on cell cycle distribution. Histograms are representative experiments and present cell cycle distribution in untreated (control) and treated HCT-116 cells with IC25, IC50and IC75.

In agreement with anti-proliferative activity of total alkaloids extract, the results of the cell cycle evaluation showed that the extract arrests cell cycle progression by significantly restricting cells in different phases (G1, S, G2/M) in a dose dependent way. The total extracted alkaloid restricted most of cell in $\mathrm{G}_{0} / \mathrm{G}_{1}$ phase at $33.7 \mu \mathrm{g} / \mathrm{ml}$. At dose $67.4 \mu \mathrm{g} / \mathrm{ml}$ it's found that most of treated cells were arrested in $S$ phase which lead to inhibit DNA synthesis. While, at dose $101 \mu \mathrm{g} / \mathrm{ml}$ The results indicated that total alkaloids inhibits cell proliferation via $\mathrm{G} 2 / \mathrm{M}$ phase arrest which also was in a dosedependent manner.

\section{Discussion}

Isoquinoline alkaloids are extracted using alcohol (methanol) were quaternary and nonquaternary alkaloids are subsequently isolated by acidification and basification of the alcoholic residue the free bases of alkaloids are soluble in organic non polar solvents. While, the salt of most alkaloids are soluble in water [20]. According to the European Pharmacopoeia, 2011. C. majus extract contain
0.2-2.8 \% of total alkaloids. The results obtained in this study agreed with the European Pharmacopoeia. (2011) where the obtained yield percentage of total alkaloids was within the reported range. The present study showed cytotoxic activity of total extracted alkaloids from C. majus on HCT-116 cell line in a dose depending manner. This study is in line with (Aljuraisy et al., 2012) who examined the cytotoxic effect of $C$. majus extract on Rhabdomyosarcoma (RD) and HeLa cell lines their findings surfaced that cytotoxic effect was in a dose and time dependent manner. Milena Deljanin et al. (2016) demonstrated that cytotoxicity effect of crud $C$. majus extract decrease viability of tumor cells in time- and dose-dependent way. The results demonstrated the concentrationdependent apoptotic-inducing potential of the extract. As a necessary corollary of the results of the cytotoxicity assay, HCT-116 cells showed a significant sensitivity to the extract. The Annexin/PI assay also confirmed the ability of the extract to induce early and late apoptosis. Unlike necrosis, apoptosis is an important cell death mechanism that does not 
trigger an inflammatory response that occasions collateral destruction of normal cells in the surrounding microenvironment [21]. Our results showed multiphasic effects during cell cycle arrest on HCT-116 cell line, which were correlated with the concentration. In agreement with anti-proliferative activity of the extract, the evaluation of the cell cycle showed that the extract arrests cell cycle progression by significantly restricting cells in different phases $(\mathrm{G} 1, \mathrm{~S}, \mathrm{G} 2 / \mathrm{M})$ in a dose dependent way. The total extracted alkaloid restricted most of cell in $\mathrm{G}_{0} / \mathrm{G}_{1}$ phase at $33.7 \mu \mathrm{g} / \mathrm{ml}$, this implies that the extract perturbs the protein synthesis that is important to cell progression from $G_{1}$ to $S$-phase. It is known that $\mathrm{p} 53$ and MDM2 proteins are important to the progression of the cell cycle at $\mathrm{G}_{0} / \mathrm{G}_{1}$ (Plasencia C. et al., 2005; Tang Y.Q. et al.,2010) [24-25]. At dose $67.4 \mu \mathrm{g} / \mathrm{ml}$ it's found that most of treated cells were arrested in $\mathrm{S}$ phase which lead to inhibit DNA synthesis. While, at dose $101 \mu \mathrm{g} / \mathrm{ml}$, the results indicated that total alkaloids inhibits cell proliferation via $\mathrm{G} 2 / \mathrm{M}$ phase arrest which also was in a dose-dependent manner. The G2 checkpoint is regulated by the activation of multiple pathways that act together to inhibit the activity of the cyclin B1/cdc2 kinase complex. p53 plays an important role in the regulation of p21 to promote cell cycle inhibition in G2 checkpoint (Flatt PM and Pietenpol JA.,2000) [26]. In comparison with Milena Deljanin's et al (2016) who studies on three different cell lines with $24 \mathrm{~h}$ incubation along with $C$. majus extract the results showed inflation of cells in G2/M phase, with reduction of cell percentage in G0/G1 phase. The fraction of cells piled up in $\mathrm{G} 2 / \mathrm{M}$ phase ensuing treatment with extract soared from $48,10 \%$ (control) to $73,38 \%$ in A549. It went up from $58,68 \%$ to $72,28 \%$ in HCT116. And it shot up from $42,81 \%$ to $69,03 \%$ in MDA-MB 231 cells. Serafim et al, (2008) who studies on melanoma cell lines, found that berberine at low doses (12.5-50 $\mu \mathrm{M})$ is concentrated in mitochondria and promotes G1 arrest. In contrast, higher doses (over $50 \mu \mathrm{M}$ ) result in cytoplasmic and nuclear berberine accumulation, and G2 arrest, their study Concluded that berberine displays multiphasic effects in these malignant cell lines, which are correlated with the concentration and intracellular distribution of this alkaloid [27]. The present study showed multiphasic effects which might due to the presence of berberine along with other types $\mathrm{pf}$ total alkaloids. According to the results mentioned above, the extracted alkaloid showed multiphasic effects of cell cycle arrest on HCT-116 cell line, which were correlated with the concentration.

\section{Acknowledgment}

Authors would like to acknowledge Dr. Zainab Yaseen/ Al-Nahrain University Biotechnology research center and Stellixir biotech company for their cooperation in accomplishing this study.

\section{Reference}

[1] Botanic gardens conservation international, 2013. (Chinese).

[2] RL Siegel, KD Miller, A Jemal., "Cancer statistics", CA Cancer J Clin., 65:5-29, 2015.

[3] R Siegel, C Desantis, A Jemal., "Colorectal cancer statistics", CA Cancer J Clin 64:104-117,2014.

[4] S Manfredi, C Lepage, C Hatem, et al., "Epidemiology and management of liver metastases from colorectal cancer", Ann Surg 244:254-259. 2006.

[5] Jemal A, Center MM, DeSantis C, Ward EM., "Global patterns of cancer incidence and mortality rates and trends", Cancer Epidemiol Biomarkers Prev, 19,1893- 1907, 2010.

[6] Colombo M, Bosisio E., "Pharmacological activities of Chelidonium majus L. (Papaveraceae)", Pharm Res.,33:127-134, 1996. doi:10.1006/phrs.1996.0019.

[7] EMA/HMPC. "Assessment report on Chelidonium majus L.", 2011/369801.

[8] Nadova S, Miadokova E, Alfoldiova L, Kopaskova M, Hasplova K, Hudecova A, et al. "Potential antioxidant activity, cytotoxic and apoptosis-inducing effects of Chelidonium majus L. extract on leukemia cells", Neuro Endocrinol Lett., 29,649-652, 2008.

[9] Yao JY, Li XL, Shen JY, Pan XY, Hao GJ, $\mathrm{Xu} \mathrm{Y}$, et al. "Isolation of bioactive components from Chelidonium majus L. with activity againts Trichodina sp. 
Aquaculture". J. Aquaculture, 318,235-238, 2011 doi: 10.1016/.2011.04.035

[10] Lee YC, Kim SH, Roh SS, Choi HY, Seo YB., "Suppressive effects of Chelidonium majus methanol extract in knee joint, regional lymph nodes, and spleen on collagen-induced arthritis in mice", J. Ethnopharmacol, 112:408, 2007 doi: 10.1016/j.jep.2007.01.033.

[11] Meng F, Zuo G, Hao X, Wang G, Xiao H, Zhang $\mathrm{J}$, et al. "Antifungal activity of the benzol[c]phenanthridine alkaloids from Chelidonium majus Linn against resistant clinical yeast isolates" J. Ethnopharmacol. 125, 494-496, 2009. doi: 10.1016/j.jep.2009.07.029.

[12] Kokoska L, Polesny Z, Rada V, Nepovim A, Vanek T. "Screening of some Siberian medicinal plants for antimicrobial activity", J. Ethnopharmacol. 82,51-53, 2002. doi:10.1016/s0378-8741.

[13] De Melo JG, Santos AG, de Amorim ELC, do Nascimento SC, de Albuquerque UP. "Medicinal plant used as antitumor agents in Brasil an ethnobotanical approach", Evid Based Complement Alternat Med. 2011; doi:10.1155/2011/365359.

[14] Harborne JB., (1984). Phytochemical method. A Guide to Modern Techniques of Plant Analysis. $2^{\text {nd }}$ ed. London. Chapman and Hall. P.307.

[15] Freshney, R.I. "Culture of Animal Cell", Wily-Liss, New York., Sixth Edition. 2012.

[16] Mosmann T., "Rapid colorimetric assay for cellular growth and survival: application to proliferation and cytotoxicity assays", J. Immunol. Methods 65,55-63. 1983.

[17] BD Biosciences FITC Annexin V Apoptosis Detection Kit I (Technical Data Sheet, Catalog no. 556547).

[18] Miller, Kelsey., "ropidium Iodide Cell Cycle Staining Protocol V1.”, Protocols.io (June 2, 2016). doi:10.17504/protocols.io.e2mbgc6.

[19] SAS. Statistical Analysis System, User's Guide. Statistical. Version 9.1th ed. 2014. SAS. Inst. Inc. Cary. N.C. USA.

[20] Bugatti, C., Colombo, M. L. and Tomé, F., "A new method for alkaloid extraction from Chelidonium majus L. Phytochem.
Anal.", 2, 65-67. 1991, doi:10.1002/pca.2800020204.

[21] Aljuraisy YH, Mahdi NK, Al-Darraji MNJ. "Cytotoxic effect of Chelidonium majus on cancer cell", Al-Anbar journal of Veterinary Sciences, 5(1):85-90, 2012.

[22] Milena Deljanin, Mladen Nikolic, Dejan Baskic, Danijela Todorovic, Predrag Djurdjevic, Milan Zaric, Milan Stankovic, Milos Todorovic, Dusko Avramovic and Suzana Popovic, "Chelidonium majus crude extract inhibits migration and induces cell cycle arrest and apoptosis in tumor cell lines", Journal of Ethnopharmacology, 10.1016/j.jep ,06.056, 2016.

[23] Elmore S., "Apoptosis A Review of Programmed Cell Death.", Toxicologic pathology.,35(4):495-516, 2007, doi:10.1080/01926230701320337.

[24] Plasencia C., Dayam R., Wang Q., "Discovery and preclinical evaluation of a novel class of small-molecule compounds in hormone-dependent and -independent cancer cell lines.", Molecular Cancer Therapeutics. 4(7):1105-1113, (2005). doi: 10.1158/1535-7163.MCT-04-0288.

[25] Tang Y.Q., Jaganath I. B., Sekaran S. D. "Phyllanthus spp. induces selective growth inhibition of PC-3 and mewo human cancer cells through modulation of cell cycle and induction of apoptosis, Journal. Pone, 5(9),2010, doi: 10.1371/journal.pone. 0012644.e12644

[26] Flatt PM and Pietenpol JA. "Mechanisms of cell-cycle checkpoints: at the crossroads of carcinogenesis and drug discovery.", Drug Metab Rev. 32:283-305, 2000.

[27] Serafim, Teresa L.; Oliveira, Paulo J.; Sardao, Vilma A.; Perkins, Ed; Parke, Donna; Holy, Jon., "Different concentrations of berberine result in distinct cellular localization patterns and cell cycle effects in a melanoma cell line.", Cancer Chemotherapy and Pharmacology., Vol. 61, No. 6. pp. 1007-1018, 2008. 